\title{
Hanford Double-Shell Tank Inspection Annual Report - Calendar Year 2012
}

\author{
TM Petermann \\ Washington River Protection Solutions \\ Richland, WA 99352 \\ U.S. Department of Energy Contract DE-AC27-08RV14800

$\begin{array}{llll}\text { EDT/ECN: } & \text { DRF } & \text { UC: N/A } & \\ \text { Cost Center: } & \text { 2KE00 } & \text { Charge Code: } & 201334 \\ \text { B\&R Code: } & \text { N/A } & \text { Total Pages: } & 27\end{array}$

Key Words: double-shell tank, inspection, ultrasonic, double-shell tank integrity project

Abstract: The double-shell tanks (DSTs) were constructed between 1968 and 1986. They will have exceeded their design life before the waste can be removed and transferred to the Waste Treatment and Immobilization Plant for vitrification. The Double-Shell Tank Integrity Project has been established to evaluate tank aging, and ensure that each tank is structurally sound for continued use. This is the first issue of the Double-Shell Tank Inspection Annual Report. The purpose of this issue is to summarize the results of DST inspections conducted from the beginning of the inspection program through the end of [calendar year] 2012. Hereafter, the report will be updated annually with summaries of the past year's DST inspection activities.

TRADEMARK DISCLAIMER. Reference herein to any specific commercial product, process, or service by trade name, trademark, manufacturer, or otherwise, does not necessarily constitute or imply its endorsement, recommendation, or favoring by the United States Government or any agency thereof or its contractors or subcontractors.

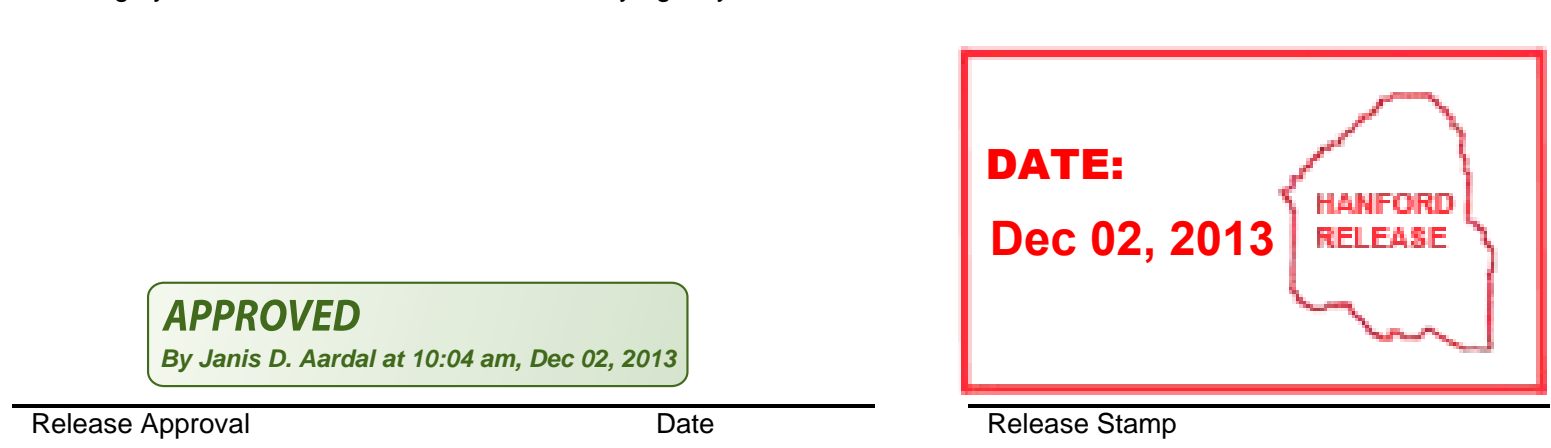

\section{Approved For Public Release}


RPP-RPT-55764

Rev. 0

\section{Hanford Double-Shell Tank Inspection Annual Report - Calendar Year 2012}

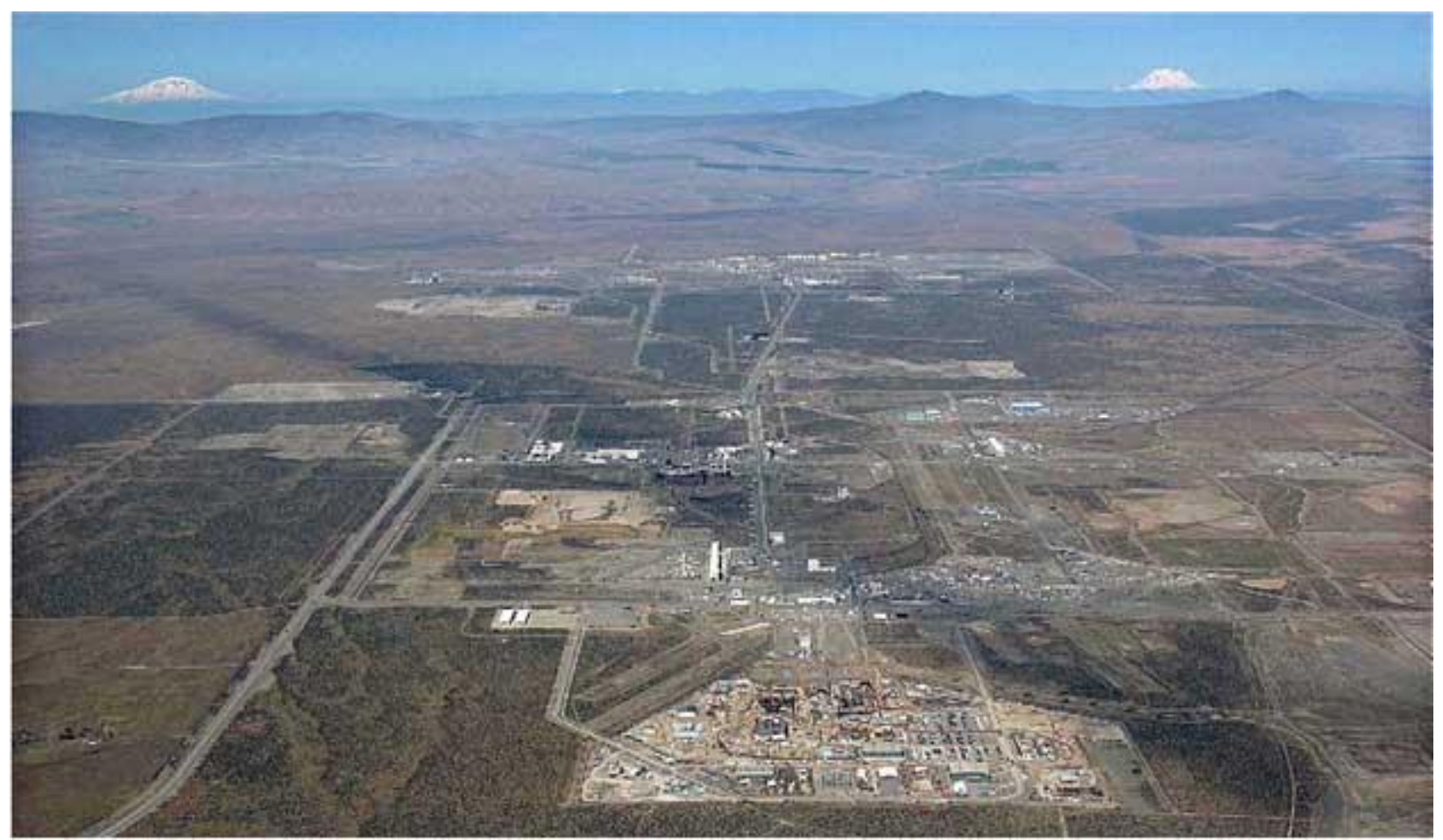

\section{washington river}

protectionsolutions

Post Office Box 850

Richland, Washington 
RPP-RPT-55764

Rev. 0

\section{Hanford Double-Shell Tank Inspection Annual Report - Calendar Year 2012}

\section{T.M. Petermann}

Washington River Protection Solutions, LLC

Date Published

December 2013

Prepared for the U.S. Department of Energy

Office of River Protection

Contract No. DE-AC27-08RV14800

Post Office Box 850

Richland, Washington 


\section{Contents}

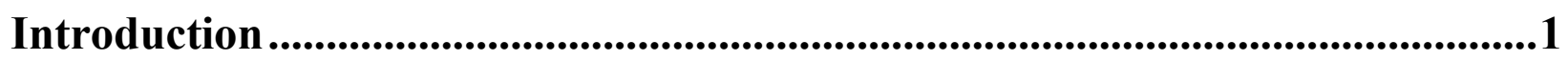

Inspection Program...................................................................................................2

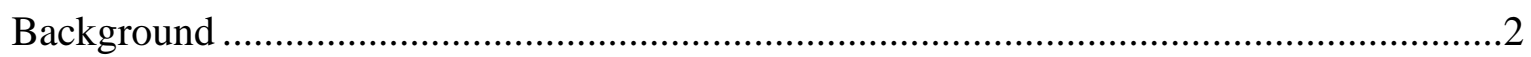

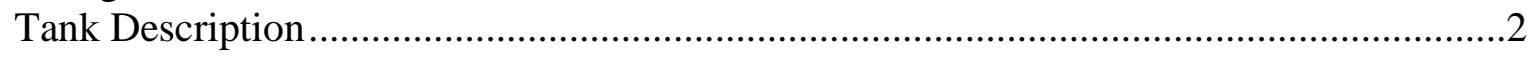

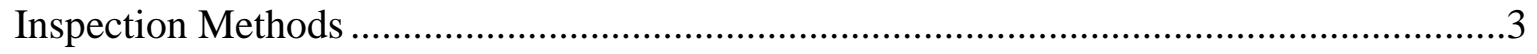

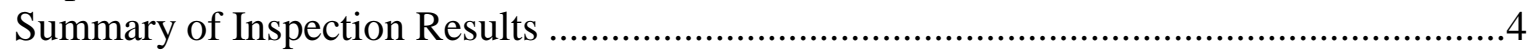

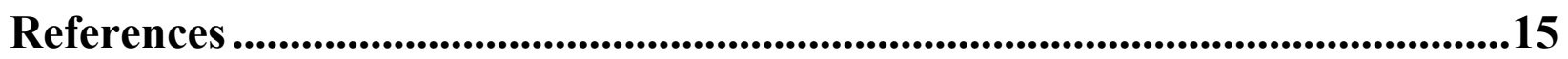

\section{Appendices}

Appendix A - Double-Shell Waste Tanks at Hanford ......................................................... A-1

Appendix B - Summary of 2012 and Prior Inspections ..................................................... 


\section{Figures}

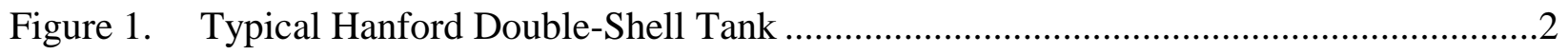

Figure 2. Tank Concrete Base Mat Construction.................................................................

Figure 3. Camera Removal from a Riser ......................................................................4

Figure 4. Tank AN-104 Dome Knuckle Bright Metal .....................................................5

Figure 5. Tank AN-106 Annulus Floor Stain....................................................................6

Figure 6. Tank AN-107 Top Knuckle Laitance Flow .........................................................6

Figure 7. Tank AP-102 Dome Dollar Plate Corrosion..........................................................

Figure 8. Tank AP-105 Tape on Annulus Wall ...........................................................

Figure 9. Tank AP-106 Dome Dollar Plate Corrosion.......................................................9

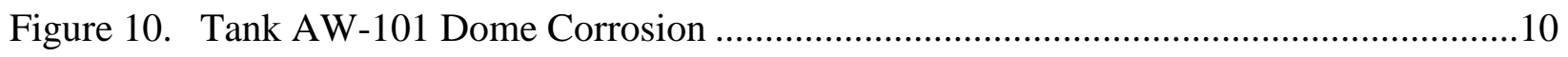

Figure 11. Tank AW-102 Dome White Deposit ............................................................. 10

Figure 12. Tank AW-104 Dome Knuckle White Deposit.........................................................11

Figure 13. Tank AW-105 Refractory Degradation .............................................................11

Figure 14. Tank AW-105 Dome White Deposits................................................................11

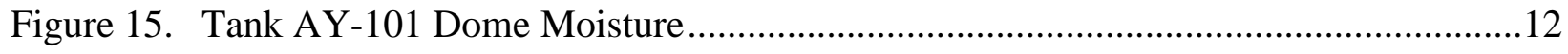

Figure 16. Tank AY-101 Waste Surface Ripple from Condensate Droplet .............................12

Figure 17. Tank AY-102 Tank Waste near Riser 90 in Annulus ...........................................13

Figure 18. Tank AZ-102 Red Streaks on Wall of Primary Tank ...........................................13

Figure 19. Tank SY-102 Dome White Deposits ................................................................14 
RPP-RPT-55764 Rev. 0

Hanford Double-Shell Tank

Inspection Annual Report - 2012

\section{Terms}

\section{Acronyms and Abbreviations}

CY

DOE

DST

DSTIP

FY

RPP

SST

TOC

TSIP

UT

WRPS

WTP

\section{Units}

$\mathrm{ft}$

gal

in.

kgal

Mgal

yr calendar year

Department of Energy

double-shell tank

Double-Shell Tank Integrity Project

fiscal year

River Protection Project

single-shell tank

Tank Operations Contractor

Tank Structural Integrity Panel

ultrasonic testing

Washington River Protection Solutions LLC

Waste Treatment and Immobilization Plant

feet

gallon

inch

thousand gallons

million gallons

year 


\section{Introduction}

Aqueous radioactive waste from World War II and Cold War Hanford nuclear fuels separation activities are stored in 28 large underground carbon steel double-shell tanks (DST).

The DSTs were constructed between 1968 and 1986. They will have exceeded their design life before the waste can be removed and transferred to the Waste Treatment and Immobilization Plant (WTP) for vitrification. The Double-Shell Tank Integrity Project (DSTIP) has been established to evaluate tank aging, and ensure that each tank is structurally sound for continued use.

This is the first issue of the DST Inspection Annual Report. The purpose of this issue is to summarize the results of DST inspections conducted from the beginning of the inspection program through the end of [calendar year] 2012. Hereafter, the report will be updated annually with summaries of the past year's DST inspection activities.

Every DST has been inspected at least twice in the past. In 2012 four tanks were visually inspected, and the walls of the primary tanks were ultrasonically examined.

Twenty-seven DSTs are classified as "Sound." During calendar year (CY) 2012 Tank 241-AY102 (AY-102), was identified as an "assumed leaker - primary tank." Additional information on Tank AY-102 can be found in RPP-ASMT-53793, Tank 241-AY-102 Leak Assessment Report.

Appendix A provides a list of DSTs at Hanford. Appendix B provides a summary of the inspections by tank. 


\section{Inspection Program}

\section{Background}

Since 1944, radioactive wastes from the processing of irradiated uranium fuels have been stored in underground tanks as alkaline slurries. Between 1968 and 1986, 28 DSTs were constructed. Their purpose was to store newly generated waste, to receive and store waste that was retrieved from the single-shell $\operatorname{tank}(\mathrm{s})$, and to stage waste for delivery to the WTP. The DSTs have capacities ranging from $1 \mathrm{Mgal}$ to $1.265 \mathrm{Mgal}$. The tanks are grouped in six tank farms located in the 200 East and 200 West areas of the Hanford Site.
The DSTs contain three types of waste: sludge, saltcake, and supernatant. The sludge is principally composed of insoluble metal oxides and insoluble fission products. The saltcake contains evaporated soluble salts. The supernatant contains liquids, dissolved salts and soluble fission products.

\section{Tank Description}

The DSTs were constructed from the same general design. They have a total working volume of about $32 \mathrm{Mgal}$. The DSTs are located underground. The top of the concrete dome is seven to eight feet below the ground surface. Figure 1 shows the typical DST layout.

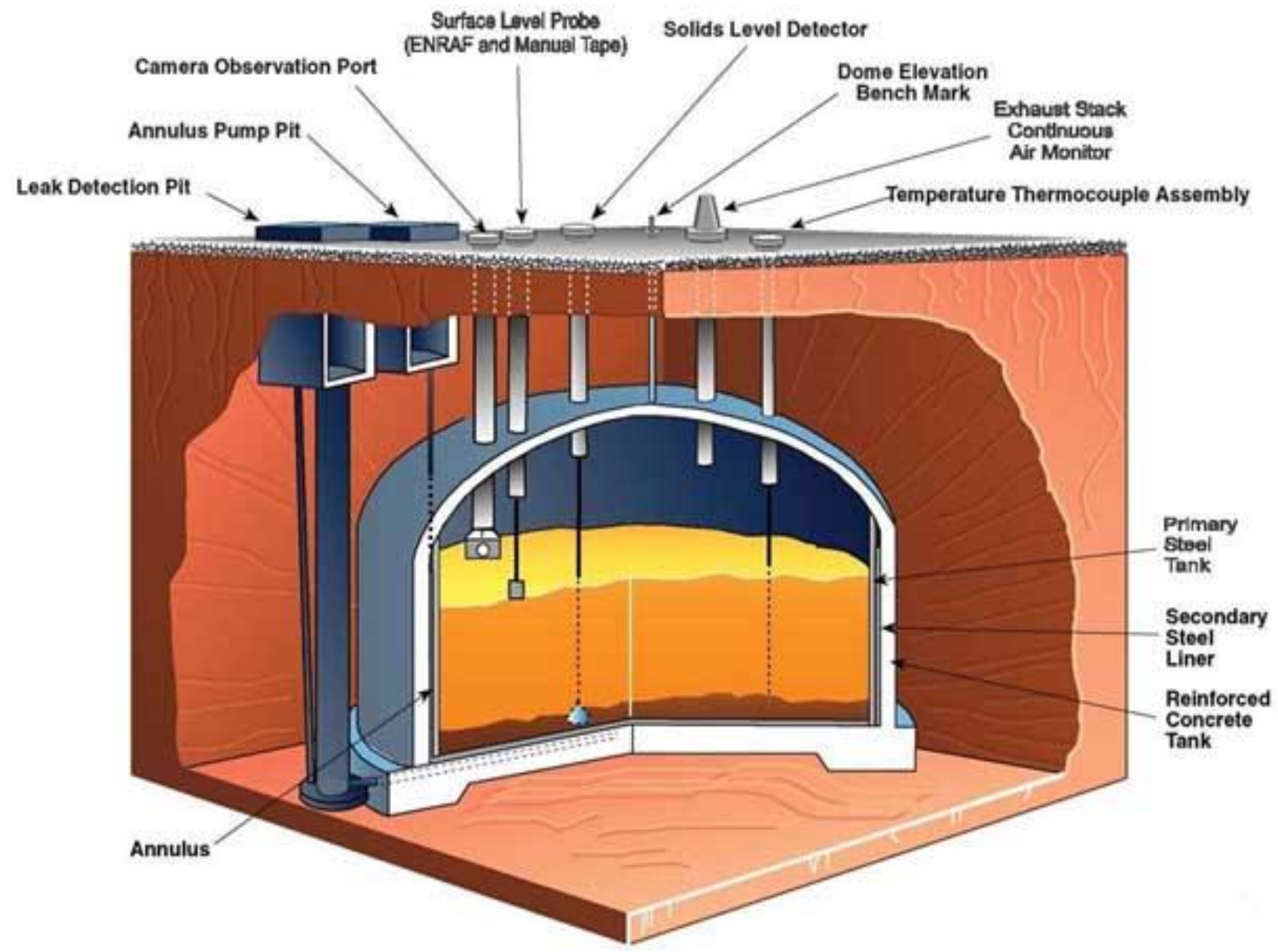

Figure 1. Typical Hanford Double-Shell Tank 
The carbon steel primary tank is $75-\mathrm{ft}$ in diameter and rests on an insulating refractory pad. The insulating refractory pad is located between the primary tank and the secondary liner. The pad has air slots to allow for air cooling of the primary tank and to direct any leakage from the primary tank into the annulus.

The carbon steel secondary liner encloses the primary tank. The liner is $80-\mathrm{ft}$ in diameter, creating a $2.5-\mathrm{ft}$ annular space between the primary tank and secondary liner.

The secondary liner meets the primary tank dome at 460-in. above the floor of the primary tank, providing double containment of radioactive waste up to that height. The metal tank structure is enclosed in a steel reinforced concrete shell.

The tank structure rests on a concrete foundation having a cross-hatch waffle grid cast in it to divert any waste leaking through the secondary liner to the leak detection pit. Figure 2 shows the foundation construction.

Each DST is equipped with three to five surface pits, which access valves and pumps used to transfer the radioactive waste between tanks.
The tanks have between 59 and 126 risers penetrating the dome and extending vertically to the ground surface. These risers provide access for video cameras, ultrasonic inspection devices, waste sampling devices, and other equipment which requires access to either the primary tank interior or the annular space.

\section{Inspection Methods}

The DSTIP includes visual inspection of the annulus and primary tank, ultrasonic testing (UT) inspection of the primary tank, and tank waste chemistry corrosion control.

The DSTs have been visually inspected for conditions both inside the primary tank (above the waste level) and on the annulus surfaces of the primary tank and secondary liner using remote video equipment. The inspection is performed on a five - seven year interval.

Inspections of the DST in-tank conditions typically focus on the primary top knuckle region, liquid-air-interface layer, and tank dome.

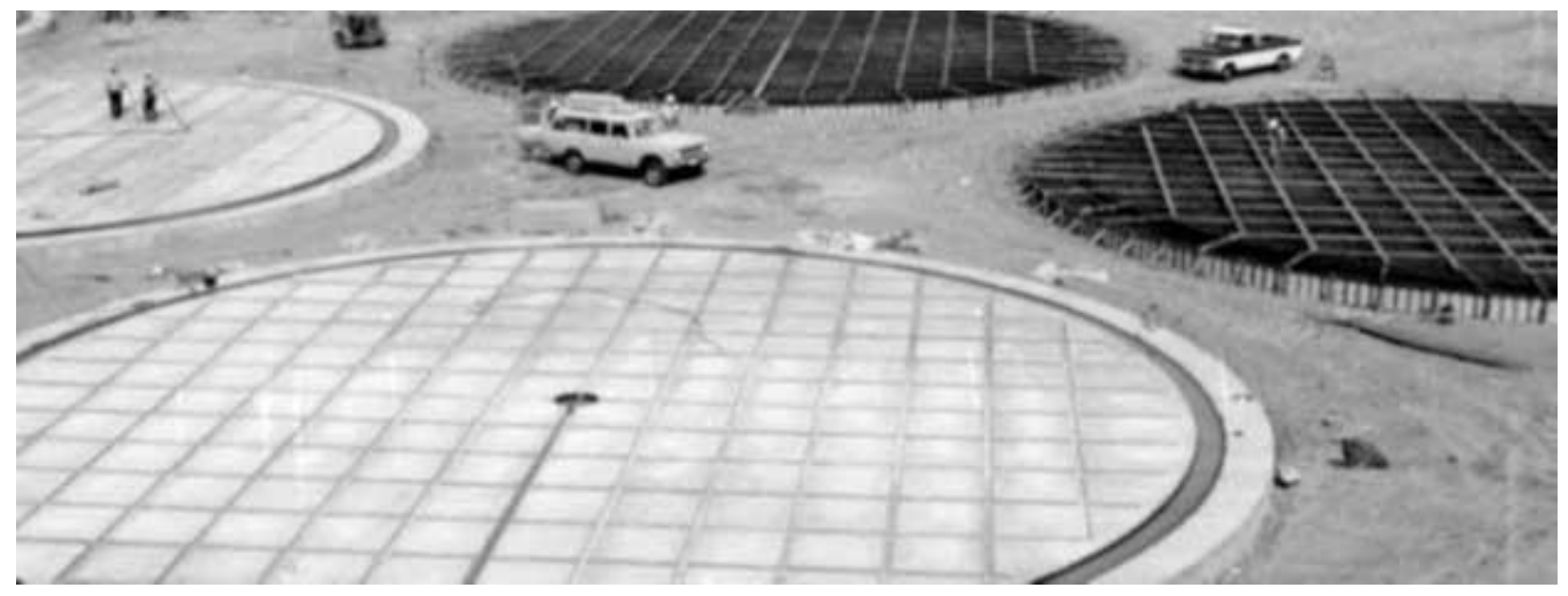

Figure 2. Tank Concrete Base Mat Construction 
High resolution, remotely-operated video cameras are used for the annulus and primary tank interior visual inspections. Beginning in 2007, the inspections have used the PTZ70 Everest Ca-Zoom ${ }^{\circledR} 6.2$ remote camera system from GE Inspection Technologies. This camera system provides improved lighting capabilities and a greater range of motion to view areas in the annulus, compared to previous cameras. Figure 3 shows workers removing a camera after inspection.

Through 2012, the annulus visual inspections were performed via an annulus riser located in each of the four quadrants of the tank. Typically, the viewable area represented about 42 percent of the annulus floor area. In 2013, the viewable area was expanded to cover at least 95 percent of the floor area by including additional risers. The annulus is inspected for water intrusion, primary tank wall surface condition, and appearance changes since the previous inspection.

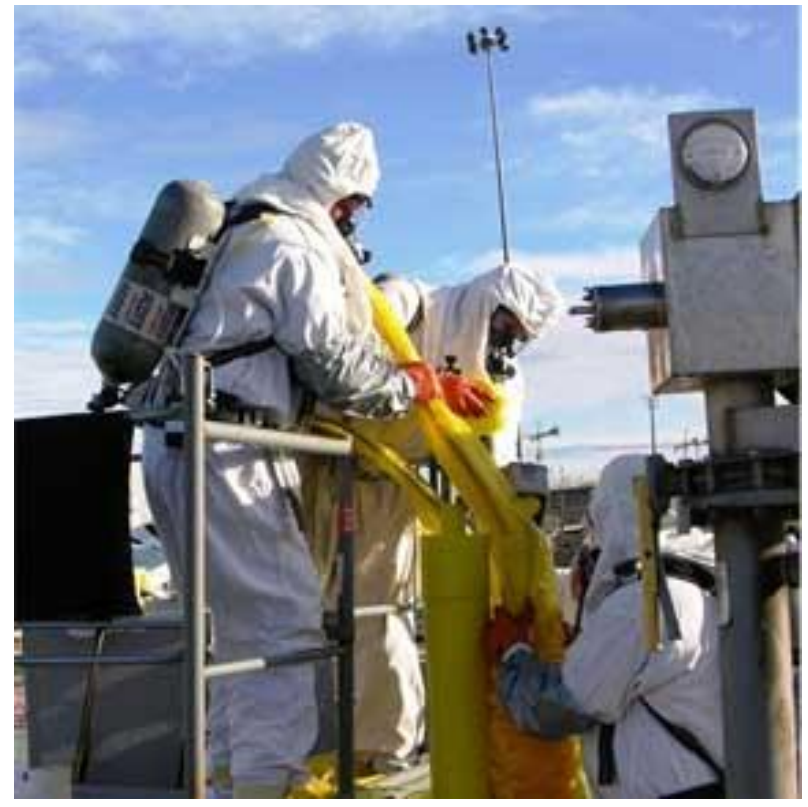

Figure 3. Camera Removal from a Riser
The primary tank visual inspection is conducted on the same frequency as the annulus visual inspection. The interior of the primary tank above the waste level is reviewed. As the DST capacity is filled, the viewable area has steadily decreased.

The primary tank walls are inspected using a remotely-operated robotic crawler for UT measurements. The UT detects thinning, pitting, and cracking. Water is used as a signal couplant. The water collects and evaporates on the annulus floor. Water stain evidence of past inspections is commonly found on the annulus floor of the DSTs.

The DSTIP UT reporting thresholds for wall thinning, pitting, and cracking are based on BNL-52527, Guidelines for Development of Structural Integrity Programs for DOE HighLevel Waste Storage Tanks, and are conservatively established as 50 percent of the BNL-52527 guidelines: thinning, 10 percent of nominal plate thickness; pitting, 25 percent of nominal plate thickness; and cracking, all detectable linear indications greater than 6-in. and 10 percent of nominal plate thickness.

\section{Summary of Inspection Results}

\section{Tank AN-101}

Visual inspections were performed in 1992, 2002, 2005, and 2011. The UT inspections were performed in 2002, 2006, and 2011.

The visual inspections of the annulus found light corrosion and mill scale on the walls. Water stains from UT couplant were found on the annulus floor.

The visual inspections of the primary tank interior found pitting on the dome interior and no evidence of cracking.

During the UT inspections, five areas were identified as wall thinning. None met the reporting threshold. There was no pitting or cracking. 


\section{Tank AN-102}

Visual inspections were performed in 1992, 2002, and 2008. The UT inspections were performed in 2001 and 2008.

The visual inspections of the annulus found light corrosion on the wall, mill scale, and minor pitting. Mill scale on the secondary liner has sloughed off, leaving behind a light layer of corrosion on the surface of the vertical wall plates.

The visual inspections of the primary tank interior found light pitting. Older in-tank piping and instrumentation are lightly corroded.

The UT inspections found three small areas of wall thinning, and no pitting or cracking. The thinned areas did not meet the reporting threshold.

\section{Tank AN-103}

Visual inspections were performed in 1992, 2002, and 2009. The UT inspection was performed in 2005 .

The visual inspections of the annulus found light corrosion and mill scale with some pitting. The refractory insulation between the primary tank and secondary tank is cracked in multiple places.

The visual inspections of the primary tank interior found general corrosion, possible pitting, and no cracking. In-tank piping and instrumentation are lightly corroded.

The UT inspection found no reportable pitting, thinning, or cracking.

\section{Tank AN-104}

Visual inspections were performed in 1992, 2002, and 2009. The UT inspection was performed in 2005.

The visual inspections of the annulus found light corrosion and mill scale with minor pitting. Laitance streaks originate along the intersection of the secondary liner and primary tank. Laitance streaks are typically either a concrete construction artifact, or evidence of rainfall or snowmelt intrusion that has made its way onto the surface of the primary tank dome before evaporating.

The visual inspections of the primary tank interior found surface corrosion and light pitting on the interior dome with no cracking. There are localized areas of the dome that appear bright in the reflected light, indicating the metal may not be passivated there (Figure 4). In-tank piping and equipment are lightly corroded.

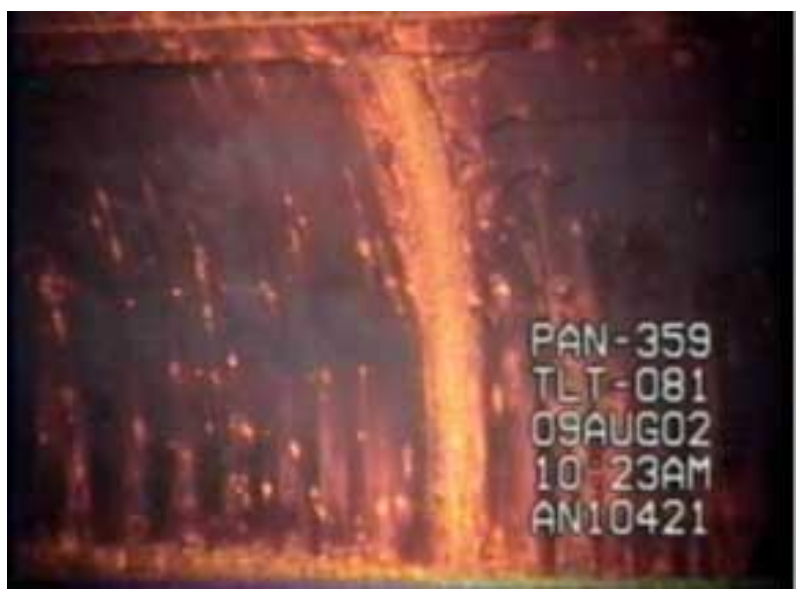

Figure 4. Tank AN-104 Dome Knuckle Bright Metal

The UT inspection found no reportable pitting, thinning, or cracking. 


\section{Tank AN-105}

Visual inspections were performed in 1992, 2006, and 2009. The UT inspections were performed in 1999, 2002, and 2006.

The visual inspections of the annulus found patches of mill scale adhered to the exterior of the primary tank with a layer of light corrosion in the regions where the mill scale has sloughed from the tank wall. There is no degradation of the dome area, haunch, primary tank or secondary liner walls, welds, or knuckle.

The visual inspections of the primary tank interior show moderate corrosion along the upper sections of the tank. Corrosion is isolated to the weld heat affected zones of the dome and top knuckle. In-tank piping and equipment are lightly corroded.

The UT inspections found no reportable pitting, thinning, or cracking.

\section{Tank AN-106}

Visual inspections were performed in 1992, 2002, 2007, and 2011. The UT inspections were performed in 1999 and 2007.

The visual inspections of the annulus found light to moderate corrosion and mill scale with minor pitting. There is no degradation of the dome area, haunch, primary tank or secondary liner walls, welds, or knuckle.

UT couplant water has accumulated on the annulus floor and evaporated (Figure 5). Corrosion is increased in the region where the couplant water was in contact with the steel.

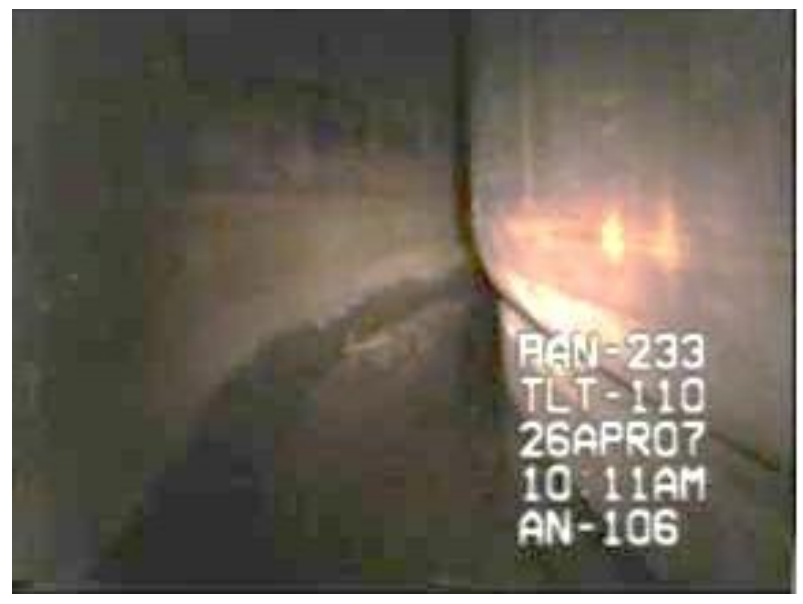

Figure 5. Tank AN-106 Annulus Floor Stain

The visual inspections of the primary tank interior found light to moderate corrosion along the dome and top knuckle sections and no cracking.

The UT inspections found no reportable pitting, thinning, or cracking.

\section{Tank AN-107}

Visual inspections were performed in 1992, 2002, 2006, and 2011. The UT inspections were performed in 1998, 2006, and 2011. There has been no change in appearance since 2002 (Figure 6).

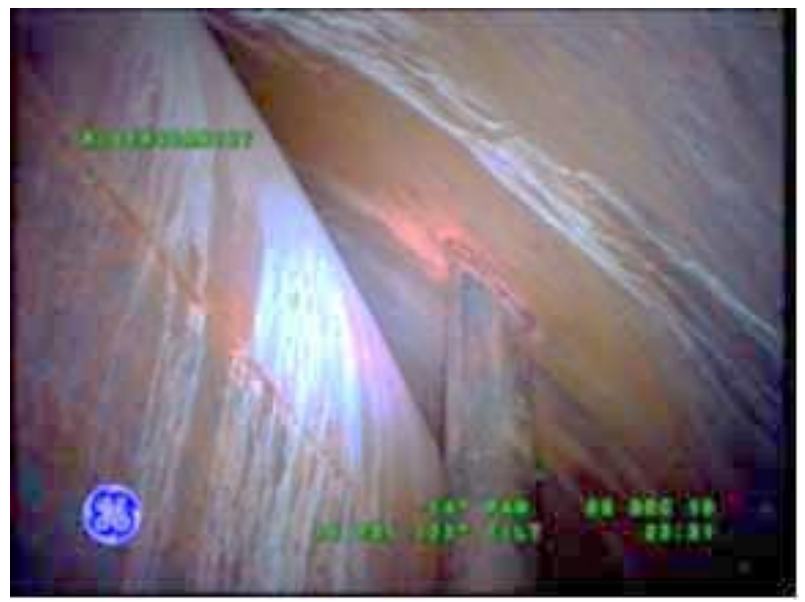

Figure 6. Tank AN-107 Top Knuckle Laitance Flow 
The visual inspections of the annulus found moderate corrosion and mill scale with minor pitting. The top knuckle is covered by laitance flow. There is no degradation of the dome area, haunch, primary tank or secondary liner walls, welds, or knuckle.

The visual inspections of the primary tank interior found pitting on the interior dome and no cracking. The tank dome mill scale has deteriorated and corrosion is present. In-tank piping is lightly corroded.

The UT inspections found no reportable pitting, thinning, or cracking.

\section{Tank AP-101}

Visual inspections were performed in 1992, 2002, and 2005. The UT inspection was performed in 2003.

The visual inspections of the annulus found light corrosion with minor pitting. There is no visible degradation of the dome area, haunch, primary tank or secondary liner walls, welds, or knuckle.

The visual inspections of the primary tank interior show light corrosion on the interior dome and no cracking.

The UT inspection found no reportable pitting, thinning, or cracking.

\section{Tank AP-102}

Visual inspections were performed in 1992, 2002, 2004, 2006, and 2009. The UT inspection was performed in 2005.

The visual inspections of the annulus found light corrosion. In 2004, a pool of couplant water was observed on the annulus floor from UT inspections completed one and two days earlier. The liquid has since evaporated, leaving behind a light layer of corrosion. There is no degradation of the dome area, haunch, primary tank or secondary liner walls, welds, or knuckle.
The visual inspections of the primary tank interior found light to moderate corrosion along the dome and top knuckle sections and no cracking. Riser penetrations through the dome are associated with the more concentrated regions of corrosion. The dome dollar plate located below the tank's central pump pit has a light layer of corrosion that is more widespread than found on other 241-AP tank dome plates (Figure 7). In-tank piping and instrumentation are lightly corroded.

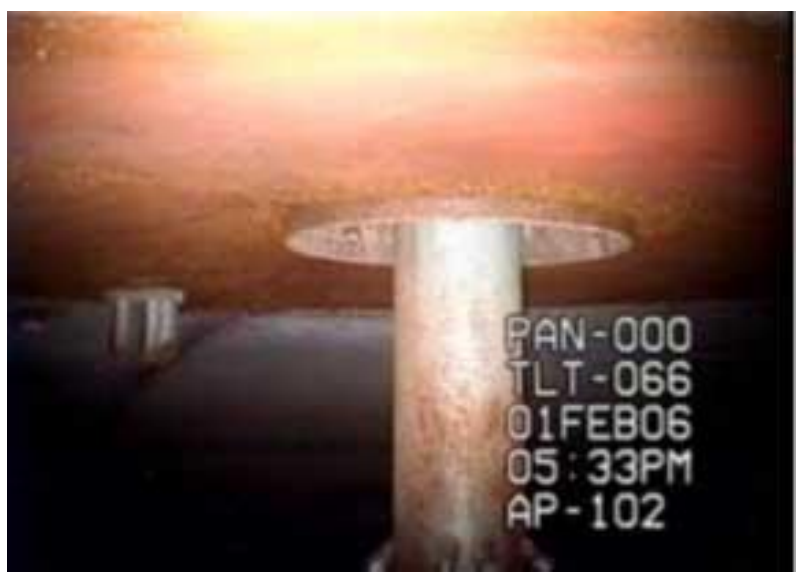

Figure 7. Tank AP-102 Dome Dollar Plate Corrosion

The UT inspection found two areas of wall thinning of 14 percent of nominal wall thickness and five areas of thinning in the weld heat affected zone of Plate Four to a maximum depth of 13 percent of nominal wall thickness. There was no reportable cracking or pitting.

\section{Tank AP-103}

Visual inspections were performed in 1992, 2005, 2006, and 2010. The UT inspections were performed in 2003 and 2010.

The visual inspections of the annulus found light corrosion on the wall of the primary tank. There was no surface degradation of the dome area, haunch, secondary liner wall, welds, or knuckle. There is evidence of evaporated UT couplant on the annulus floor. 
The visual inspections of the primary tank interior show significant amounts of moisture on the tank wall. There is evidence of light pitting on the tank dome. The majority of the tank interior is lightly corroded with no cracking or pitting.

The UT inspections found no reportable wall thinning, pitting or cracking. A linear indication and a gouge were discovered during the 2003 UT inspection. The linear indication was determined to be a small region of incomplete fusion. The gouge is thought to be a construction artifact. These anomalies were evaluated and determined to have no effect on the structural integrity of the primary tank. There has been no change in the linear indication or the gouge between inspections.

\section{Tank AP-104}

Visual inspections were performed in 1992, 1997, 2005, 2006, and 2009. The UT inspection was performed in 2004.

The visual inspections of the annulus found light corrosion. Riser 49 shows light corrosion from laitance streaks identified during the 2004 inspection. There has been no change in the appearance or extent of involvement between the inspections. There is no degradation of the dome area, haunch, primary tank or secondary liner walls, welds, or knuckle.

The visual inspections of the primary tank interior show light corrosion with no pitting or cracking. Surface corrosion is present in the areas where risers penetrate the dome.

The UT inspection found no reportable pitting, thinning, or cracking.

\section{Tank AP-105}

Visual inspections were performed in 1992, 2006, and 2012. The UT inspections were performed in 2003 and 2012.

The visual inspections of the annulus found light corrosion. Areas of the primary tank wall are covered with strips of tape left from construction (Figure 8). These areas have shown no change in appearance between inspections. There was no degradation of the dome area, haunch, primary tank or secondary liner walls, welds, or knuckle.

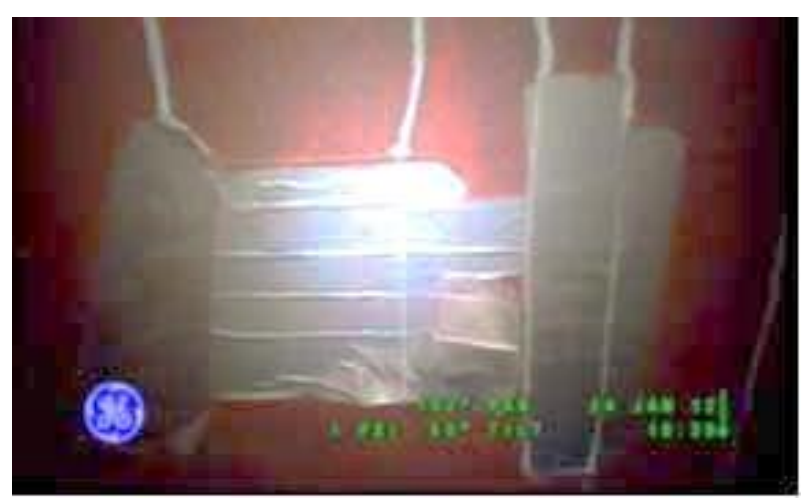

Figure 8. Tank AP-105 Tape on Annulus Wall

The visual inspections of the primary tank interior found light corrosion on the lower portion of the interior dome and no cracking. The top knuckle has light to moderate corrosion, more notable in the weld heat affected zones. In-tank piping and instrumentation are lightly corroded.

The UT inspection found no reportable pitting, thinning, or cracking of the tank wall.

\section{Tank AP-106}

Visual inspections were performed in 1992, 2004, 2006, and 2009. The UT inspection was performed in 2005. 
The visual inspections of the annulus found light corrosion and some pitting. The condition of the primary tank dome area, haunch, primary tank and secondary walls, welds, and knuckle has not changed between inspections.

The visual inspections of the primary tank interior found light corrosion concentrated on the tank dome plates. The risers are covered with light corrosion. In-tank piping and instruments are lightly corroded.

The UT inspection found no reportable pitting, thinning, or cracking.

\section{Tank AP-107}

Visual inspections were performed in 1992, 2002, 2007, and 2008. The UT inspections were performed in 2000 and 2007.

The visual inspections of the annulus found light corrosion with some pitting along circumferential welds joining the course plates together. There is no visible degradation of the dome area, haunch, primary tank or secondary liner walls, welds, or knuckle.

The visual inspections of the primary tank interior found pitting on the dome and no cracking. Corrosion appears along the dome welds and the center tank dollar plate located below the central pump pit (Figure 9).

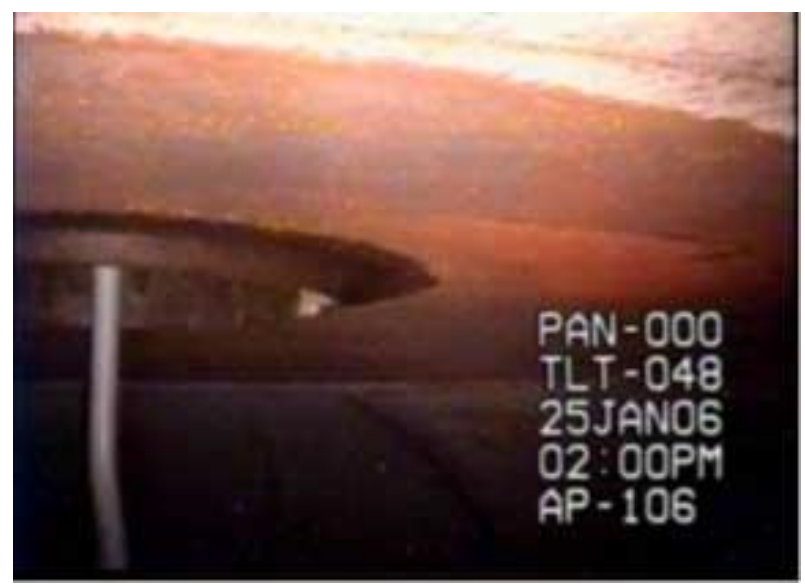

Figure 9. Tank AP-106 Dome Dollar Plate Corrosion
Surface corrosion is present where the risers penetrate the dome. In-tank piping is lightly corroded.

The UT inspection found no reportable pitting, thinning, or cracking.

\section{Tank AP-108}

Visual inspections were performed in 1992, 2002, 2008, and 2012. The UT inspections were performed in 2000, 2002, and 2008, and 2012.

The visual inspections of the annulus found light corrosion with some pitting. The annulus floor contains a significant amount of rust colored material with no change in appearance between the last two inspections. There are cracks in the insulating refractory.

The visual inspections of the primary tank interior found light pitting, areas of corrosion on the interior dome, and no cracking. The riser penetrations are in good condition with some corrosion located in the nearby areas.

The UT inspections identified four areas of reportable wall thinning, no reportable pitting, and a reportable linear indication in fiscal year (FY) 2002. The linear indication was evaluated and determined to have no effect on the structural integrity of the primary tank. The indication was inspected in 2008 and was unchanged.

\section{Tank AW-101}

Visual inspections were performed in 1991, 2001, 2008, 2009, and 2012. The UT inspections were performed in 2001 and 2009.

The visual inspections of the annulus found light corrosion. The wall mill scale continues to deteriorate. Light corrosion is visible along the base metal where the mill scale has sloughed off. 
The visual inspections of the primary tank interior found light corrosion. Along the top section of the tank dome, directly below the central pump pit, there is isolated corrosion (Figure 10). The likely cause is condensation or liquid from the pump pit draining from the nearest riser penetrations and repeatedly wetting the surface.

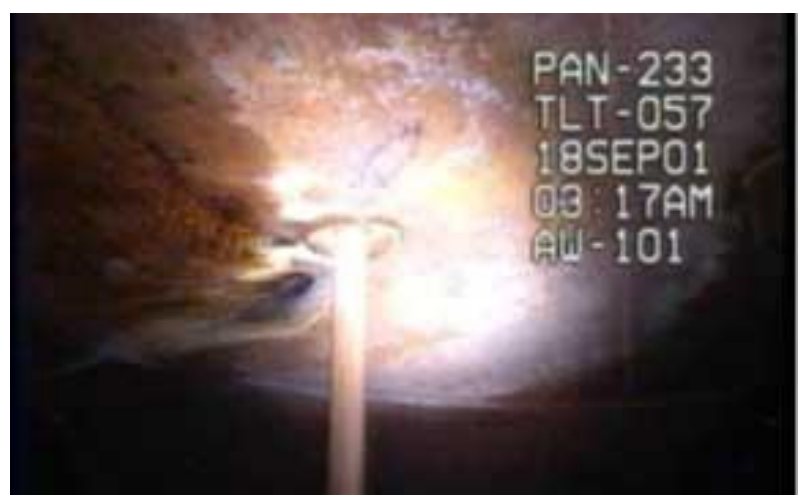

Figure 10. Tank AW-101 Dome Corrosion

The UT inspections found no reportable pitting or cracking, and one reportable area of wall thinning of 16 percent of nominal wall thickness. The area has remained stable between UT inspections.

\section{Tank AW-102}

Visual inspections were performed in 1991 and 2001. The UT inspections were performed in 2002 and 2010.

The visual inspections of the annulus found light corrosion, continuing mill scale deterioration, and some pitting. There is no significant degradation of the dome area, haunch, primary tank or secondary liner walls, welds, or knuckle.

The visual inspections of the primary tank interior found light corrosion on the wall. There is a white deposit originating from the central pump pit (Figure 11). The appearance of the metal surface involved with the deposit has not changed between inspections. In-tank piping and instrumentation are lightly corroded.

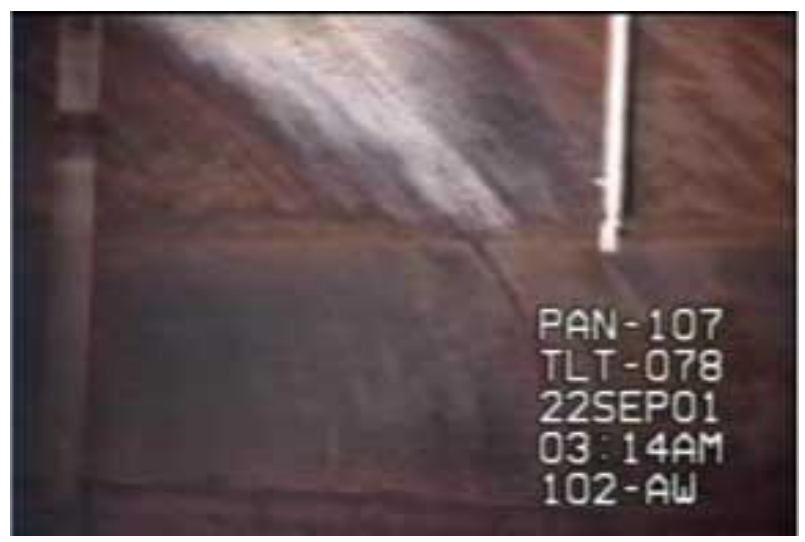

Figure 11. Tank AW-102 Dome White Deposit

The UT inspection found no reportable pitting, thinning, or cracking.

\section{Tank AW-103}

Visual inspections were performed in 1991, 2002, 2006, 2007, and 2011. The UT inspections were performed in 1997 and 2006.

The visual inspections of the annulus found light corrosion on the surface of the primary tank. There is no significant corrosion in the dome area, haunch, primary tank or secondary liner wall, welds, or knuckle.

The visual inspections of the primary tank interior found light corrosion on the tank wall. The knuckle has light to moderate corrosion along the circumferential welds.

The UT inspection found no reportable pitting, thinning, or cracking.

\section{Tank AW-104}

Visual inspections were performed in 1991, 2001, 2009, and 2010. The UT inspections were performed in 2002 and 2010.

The visual inspections of the annulus found light corrosion and mill scale that is unchanged since the tank was placed in service. 
The visual inspections of the primary tank interior found surface corrosion on the dome and no cracking. The knuckle surface contains a white deposit which is not typically seen at that level (Figure 12). In-tank piping and instrumentation are lightly corroded.

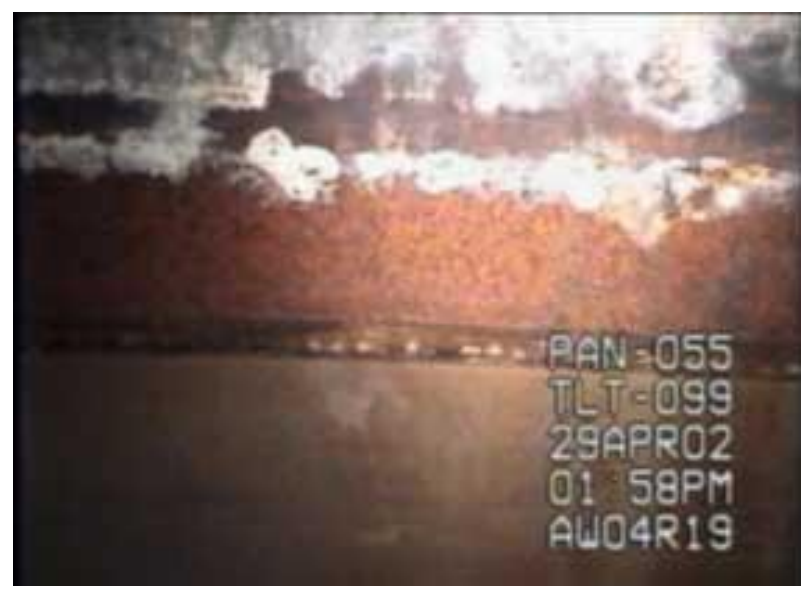

Figure 12. Tank AW-104 Dome Knuckle White Deposit

The UT inspection found no reportable pitting, thinning, or cracking.

\section{Tank AW-105}

Visual inspections were performed in 1991, 2001, 2008, and 2009. The UT inspections were performed in 2001 and 2009.

The visual inspections of the annulus found mill scale still separating from the base steel. Light surface corrosion is present on the base steel where the mill scale has sloughed off. There is no significant corrosion in the dome area, haunch, primary tank or secondary liner walls, welds, or knuckle

The insulating refractory is cracking in multiple regions (Figure 13). Cracking is more concentrated in the illustrated area than in others. There has been no change in appearance between inspections.

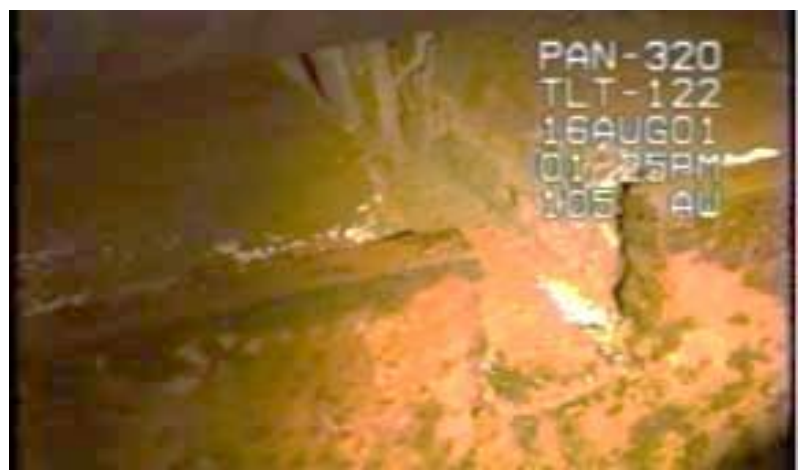

Figure 13. Tank AW-105 Refractory Degradation

The visual inspections of the interior found light surface corrosion. The top section of the dome, directly below the central pump pit, has a white deposit (Figure 14) similar to Tank AW-102 deposit. This type of deposit is visible in other DSTs in the region of the central pump pit. Its origin is typically drainage or condensation from the nearest penetrations wetting the dome surface.

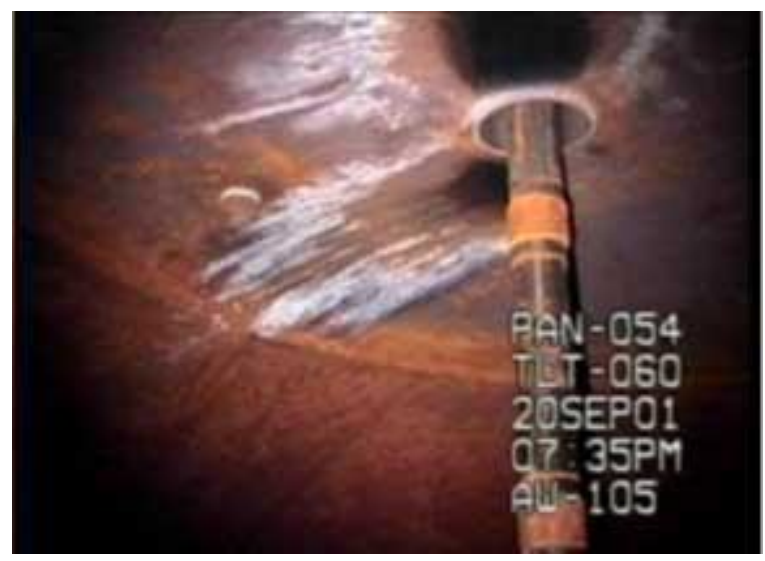

Figure 14. Tank AW-105 Dome White Deposits

The UT inspection found no reportable pitting, thinning, or cracking.

\section{Tank AW-106}

Visual inspections were performed in 1991, 2001, and 2009. The UT inspections were performed in 2002 and 2009. 
The visual inspections of the annulus found mill scale still attached to the primary tank wall exterior. There is no significant corrosion in the dome area, haunch, primary tank or secondary liner walls, welds, or haunch.

The visual inspections of the primary tank found light corrosion on the dome. Pitting is evident in some areas. There is a white deposit originating from the central pump pit. There has been no change in the appearance of the metal surface associated with the deposit between inspections. In-tank piping and instrumentation are lightly corroded.

The UT inspection found one area of reportable wall thinning at the 273-in. level in a vertical weld heat affected zone. There was no reportable pitting or cracking.

\section{Tank AY-101}

Visual inspections were performed in 1992, 2001, 2007, 2008, and 2009. The UT inspections were performed in 2002 and 2009.

The visual inspections of the annulus found moderate to heavy corrosion, mill scale, pitting, and steel exfoliation. Multiple laitance streaks originate from the top knuckle region indicative of surface water intrusions that have evaporated.

The visual inspections of the primary tank interior found moderate corrosion and moisture on the tank dome with no cracking. Corrosion is evident primarily in the weld heat affected zones. In 2006, the inspection showed significant amounts of condensation on the dome (Figure 15) and on walls. A water droplet was seen falling from a tank dome stain (Figure 16).

The UT inspections found 38 areas of reportable wall thinning, no reportable pitting and no cracking. One area of wall thinning exceeded the 20 percent wall thinning acceptance criteria.

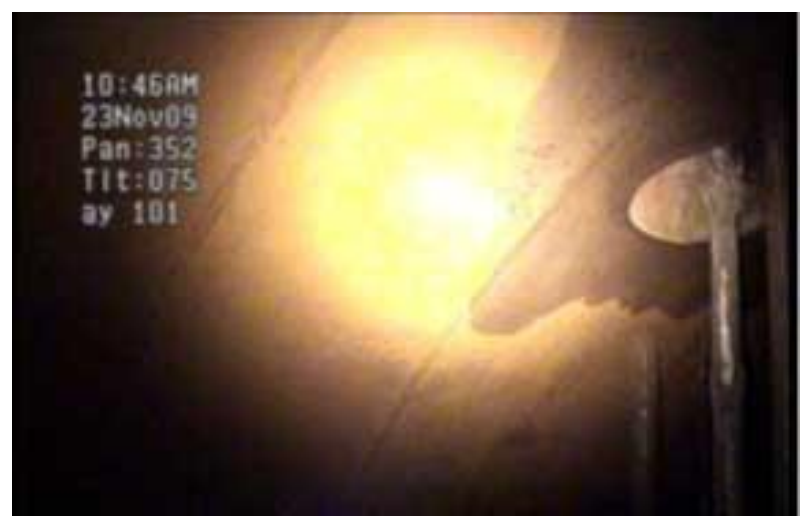

Figure 15. Tank AY-101 Dome Moisture

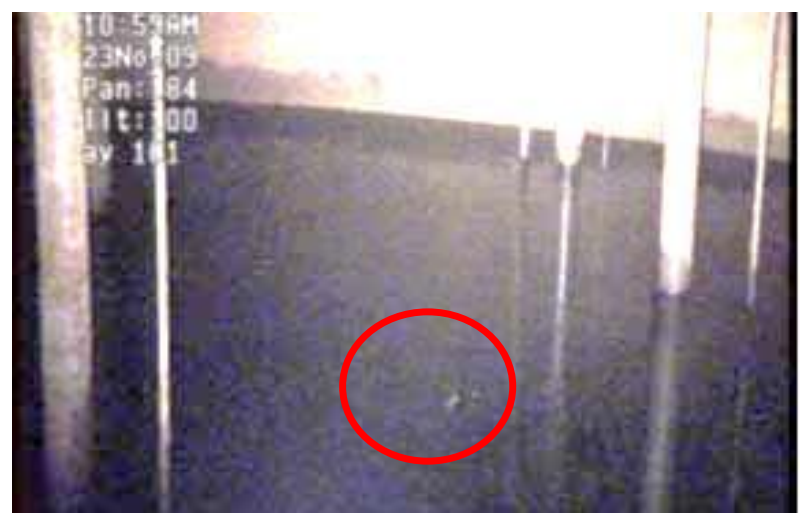

Figure 16. Tank AY-101 Waste Surface Ripple from Condensate Droplet

\section{Tank AY-102}

Visual inspections were performed in 1992, 2001, 2003, 2006, and 2012. The UT inspections were performed in 2002 and 2009.

The visual inspections of the annulus found moderate to heavy corrosion with some pitting. Corrosion is present on the primary shell concentrated in the top knuckle region and circumferential welds. Laitance streaks similar to Tank AY-101 have appeared, indicative of surface water intrusions that have evaporated.

During the 2012 annulus inspection, tank waste was discovered on the annulus floor near Riser 90 (Figure 17). Additional tank waste material was discovered on the annulus floor near Riser 83. The primary tank was declared an "assumed leaker - primary tank" in October 2012. 


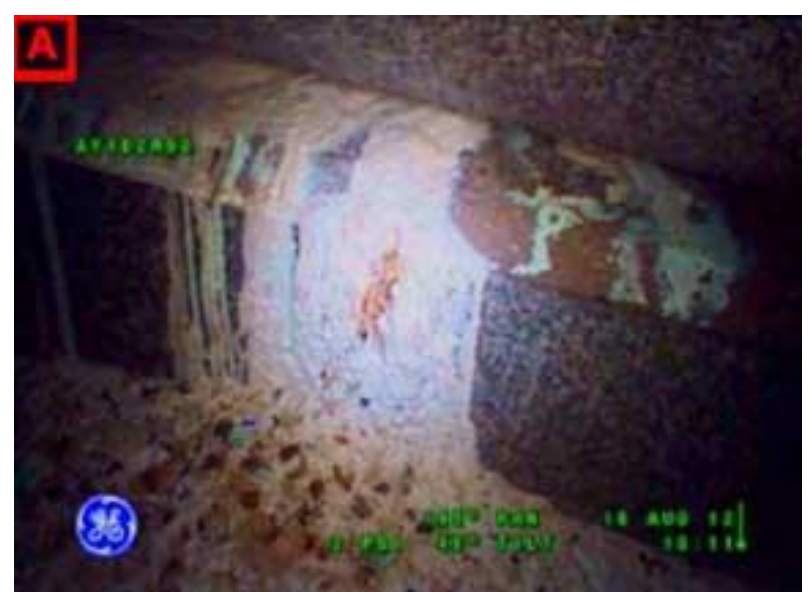

Figure 17. Tank AY-102 Tank Waste near Riser 90 in Annulus

An area of translucent crystalline material adhering to the tank dome surface was found near Riser 87. This area was determined to be above the tank waterline and therefore not a third leak site.

The visual inspections of the primary tank interior showed light to moderate corrosion on the tank dome. Surface wetting above the liquid-air interface is apparent. Condensation tracks and white deposits are visible.

The UT inspections found 22 areas reportable of wall thinning. None exceeded the 20 percent acceptable criteria. There was no detectable pitting or cracking.

\section{Tank AZ-101}

Visual inspections were performed in 1993, 2001, and 2007. The UT inspections were performed in 1999 and 2007.

The visual inspections of the annulus found light to moderate mill scale with minor pitting. White material present on the secondary wall was determined to be a construction artifact that originated from the annulus pump pit.

The visual inspections of the primary tank interior found a layer of moderate corrosion along the primary wall. In-tank equipment has light corrosion.
The UT inspections found a localized area of wall thinning. Evaluation concluded that the area was most likely a construction defect, due to its shape and the absence of other nearby wall thinning areas. There is no reportable wall thinning, pitting, or cracking.

\section{Tank AZ-102}

Visual inspections were performed in 1993, 2001, and 2007. The UT inspection was performed in 2003.

The visual inspections of the annulus found light corrosion and mill scale with minor pitting near the weld heat affected zones. The mill scale deterioration is more prevalent on the secondary liner wall. Red streaks are visible on the primary tank wall (Figure 18). The origin has not been identified, but the appearance has not changed between inspections.

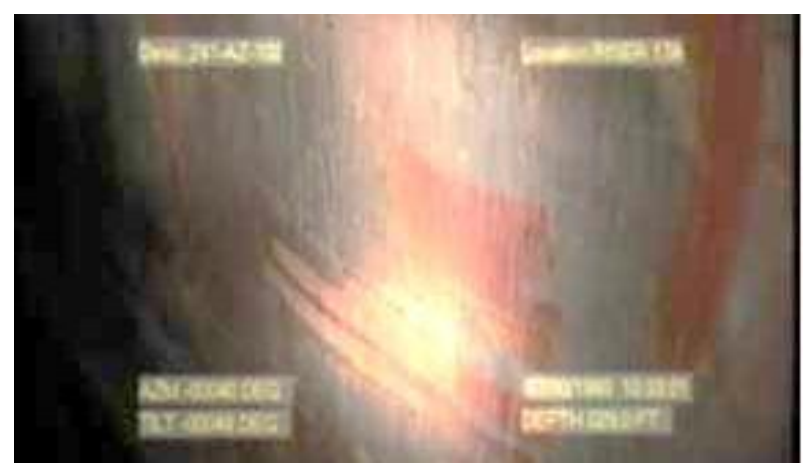

Figure 18. Tank AZ-102 Red Streaks on Wall of Primary Tank

The 2007 visual inspection of the primary tank interior has hampered by headspace fog and limited lighting. There is widespread condensation on the tank wall. The origin of this surface moisture appears to be the apex of the tank dome. Corrosion and light pitting are present.

The 2003 UT inspection found nine areas of wall thinning ranging from 10.9 to 16.8 percent thinning. These areas were all located above the maximum operating level for the tank and did not exceed the reporting threshold. 


\section{Tank SY-101}

Visual inspections were performed in 1993, 2000, 2003, and 2008. The fourth round of visual inspections began in 2012 and finished in 2013. The UT inspections were performed in 2003 and 2004.

The visual inspections of the annulus show a layer of light corrosion along the bottom knuckle. The appearance has remained stable between inspections.

The visual inspections of the primary tank interior found light corrosion on the tank wall, with more concentrated corrosion along the welds. There is surface discoloration in the central pump pit region that has not changed between inspections. White deposits were first observed in the area during the 2008 inspection.

The UT inspection found multiple areas of wall thinning during the vertical scan of the top transition plate and liquid-air interface as well as the vertical welds of the top transition plate. None exceeded the reporting threshold.

\section{Tank SY-102}

Visual inspections were performed in 1993, 2003, 2008, and 2009. The UT inspection was performed in 2004.

The visual inspection of the annulus found mill scale deterioration and light corrosion. There is no degradation of the dome area, haunch, primary tank or secondary liner wall, welds, or knuckle.

The visual inspections of the primary tank interior found light corrosion on the primary tank wall. White deposits layered along the tank dome originate from a riser (Figure 19). There has been no change in appearance of this area since the first inspection in 1993.

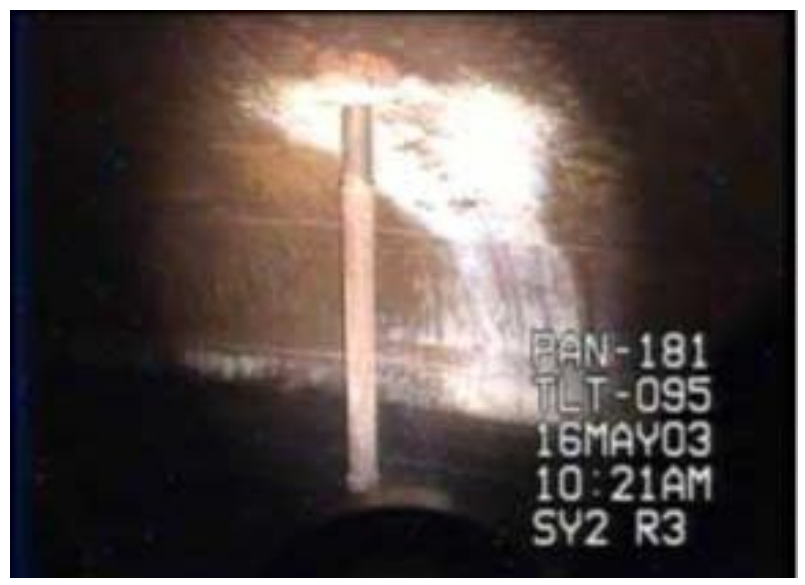

Figure 19. Tank SY-102 Dome White Deposits

The UT inspection found multiple areas of reportable wall thinning in the top transition plate, located above the maximum operating level of the tank. The cause is unknown. There was no reportable wall thinning in any of the other plate areas examined. There were no reportable indications of pitting or cracking.

\section{Tank SY-103}

Visual inspections were performed in 1993, 2003, and 2009. The fourth round of visual inspections began in 2012 and finished in 2013. The UT inspection was performed in 2004.

The visual inspections of the annulus found light corrosion on the primary tank exterior with laitance streaks originating from high on the primary tank dome. The appearance has not changed between inspections.

The visual inspections of the primary tank interior found light to moderate corrosion and signs of continuing exfoliation of the mill scale.

The UT inspections found six reportable areas of wall thinning in the top transition plate ranging from 10.4 percent to 12.8 percent of nominal plate thickness. These areas were all located above the maximum operating level for the tank. There was no pitting or cracking. 
RPP-RPT-55764 Rev. 0

Hanford Double-Shell Tank

Inspection Annual Report - 2012

\section{References}

BNL-52527, 1997, Guidelines for Development of Structural Integrity Programs for DOE HighLevel Waste Storage Tanks, Rev. 0, Department of Energy, Richland, Washington.

HNF-EP-0182, 2013, Waste Tank Summary Report for Month Ending February 28, 2013, Rev. 299, Washington River Protection Solutions, LLC, Richland, Washington.

RPP-ASMT-53793, 2012, Tank 241-AY-102 Leak Assessment Report, Rev. 0, Washington River Protection Solutions LLC, Richland, Washington. 


\section{Appendix A - Double-Shell Waste Tanks at Hanford}

\begin{tabular}{|c|c|c|}
\hline Tank farm & Construction period & \multicolumn{1}{c|}{ Storage capacity } \\
\hline AN & $1980-1982$ & 7 tanks with a capacity of $1.16 \mathrm{Mgal}$ \\
\hline AP & $1982-1986$ & $\begin{array}{l}4 \text { tanks with a capacity of } 1.16 \mathrm{Mgal} \\
4 \text { tanks with a capacity of } 1.265 \mathrm{Mgal}\end{array}$ \\
\hline AW & $1976-1980$ & 6 tanks with a capacity of $1.16 \mathrm{Mgal}$ \\
\hline AY & $1968-1970$ & 2 tanks with a capacity of $1.018 \mathrm{Mgal}$ \\
\hline AZ & $1970-1974$ & 2 tanks with a capacity of $1.018 \mathrm{Mgal}$ \\
\hline SY & $1974-1976$ & 3 tanks with a capacity of $1.16 \mathrm{Mgal}$ \\
\hline
\end{tabular}




\section{Appendix B - Summary of 2012 and Prior Inspections}

\begin{tabular}{|c|c|c|c|c|}
\hline Farm & Tank & $\begin{array}{c}\text { Tank leak } \\
\text { integrity status }\end{array}$ & Year of visual inspection & Year of ultrasonic testing \\
\hline \multirow[t]{7}{*}{$\begin{array}{l}241-\mathrm{AN} \\
\text { Farm }\end{array}$} & AN-101 & Sound & 1992, 2002, 2005, 2011 & 2002, 2006, 2011 \\
\hline & AN-102 & Sound & $1992,2002,2008$ & 2001,2008 \\
\hline & AN-103 & Sound & $1992,2002,2009$ & 2005 \\
\hline & AN-104 & Sound & 1992, 2002, 2009 & 2005 \\
\hline & AN-105 & Sound & 1992, 2006, 2009 & 1999, 2002, 2006 \\
\hline & AN-106 & Sound & 1992, 2002, 2007, 2011 & 1999, 2007 \\
\hline & AN-107 & Sound & 1992, 2002, 2006, 2011 & 1998, 2006, 2011 \\
\hline \multirow[t]{8}{*}{$\begin{array}{l}\text { 241-AP } \\
\text { Farm }\end{array}$} & AP-101 & Sound & $1992,2002,2005$ & 2003 \\
\hline & AP-102 & Sound & $\begin{array}{c}1992,2002,2004,2006, \\
2009\end{array}$ & 2005 \\
\hline & AP-103 & Sound & $1992,2005,2006,2010$ & 2003,2010 \\
\hline & AP-104 & Sound & $\begin{array}{c}1992,1997,2005,2006, \\
2009\end{array}$ & 2004 \\
\hline & AP-105 & Sound & 1992, 2006, 2012 & 2003, 2012 \\
\hline & AP-106 & Sound & 1992, 2004, 2006, 2009 & 2005 \\
\hline & AP-107 & Sound & $1992,2002,2007,2008$ & 2000, 2007 \\
\hline & AP-108 & Sound & 1992, 2002, 2008, 2012 & $2000,2002,2008,2012$ \\
\hline \multirow[t]{6}{*}{$\begin{array}{l}\text { 241-AW } \\
\text { Farm }\end{array}$} & AW-101 & Sound & $\begin{array}{c}1991,2001,2008 \\
2009,2012\end{array}$ & 2001, 2009 \\
\hline & AW-102 & Sound & 1991, 2001 & 2002,2010 \\
\hline & AW-103 & Sound & $\begin{array}{c}1991,2002,2006 \\
2007,2011\end{array}$ & 1997,2006 \\
\hline & AW-104 & Sound & $1991,2001,2009,2010$ & 2002,2010 \\
\hline & AW-105 & Sound & 1991, 2001, 2008, 2009 & 2001, 2009 \\
\hline & AW-106 & Sound & 1991, 2001, 2009 & 2002,2009 \\
\hline \multirow[t]{2}{*}{$\begin{array}{l}\text { 241-AY } \\
\text { Farm }\end{array}$} & AY-101 & Sound & $\begin{array}{c}1992,2001,2007 \\
2008,2009\end{array}$ & 2002,2009 \\
\hline & AY-102 & $\begin{array}{l}\text { Assumed Leaker- } \\
\text { Primary Tank }\end{array}$ & $\begin{array}{c}1992,2001,2003, \\
2006,2012\end{array}$ & 2002,2009 \\
\hline \multirow[t]{2}{*}{$\begin{array}{l}\text { 241-AZ } \\
\text { Farm }\end{array}$} & AZ-101 & Sound & 1993, 2001, 2007 & 1999, 2007 \\
\hline & AZ-102 & Sound & 1993, 2001, 2007 & 2003 \\
\hline \multirow[t]{3}{*}{$\begin{array}{c}\text { 241-SY } \\
\text { Farm }\end{array}$} & SY-101 & Sound & 1993, 2000, 2003, 2008 & 2003,2004 \\
\hline & SY-102 & Sound & 1993, 2003, 2008, 2009 & 2004 \\
\hline & SY-103 & Sound & 1993, 2003, 2009 & 2004 \\
\hline
\end{tabular}

